\title{
A Look into Literature Courses in Pre-Service Teacher Training
}

\author{
Abdu M. Al-kadi' ${ }^{1}$ Taha Ahmed Hasan Hezam² \\ ${ }^{1}$ Department of English, Ibb University, Yemen https://orcid.org/0000-0003-3805-7507 \\ ${ }^{2}$ Department of English, University of Bisha, Saudi Arabia \& Taiz University, Yemen \\ https://orcid.org/0000-0001-5779-0574 \\ Corresponding author: Abdu Al-kadi [findtalib@gmail.com]
}

\begin{abstract}
Received: $27 / 04 / 2021$
Accepted: 20/06/2021

Published: 30/06/2021

Abstract: This paper explored the load of literature courses in the teacher-training program at the collegiate level in Yemen. It dwells on teacher candidates' perceptions of the current status quo of literature teaching based on the learner-centered approach and humanistic curriculum. Data were elicited through an opinion poll from a sample of senior prospective teachers $(n=112)$ who have undertaken courses in verse, fiction, and prose embedded in the program. Findings ensued from this analysis show that the participants had a wealth of difficulties that hamper achieving the objectives of embedding literature in the program, and most of such difficulties stem from teaching inadequacies in the given context. The study brings to the foreground some insightful ideas into curriculum reform. It generally informs the curriculum designers to readdress the existing program with an eye on the underestimated literature courses. It recommends that the overhaul of the existing syllabus should be fashioned to a new purpose, a new footing and a new perspective in line with the worldwide, extemporized changes in terms of curriculum development. A balanced approach to literature instruction to link the school curriculum with what is taught at the tertiary level would be a stepping-point to an improved literature teaching scenario.
\end{abstract}

Keywords: ELT; literature; pre-service teachers; needs analysis

\section{Introduction}

There is relatively little dispute that learning a language would be incomplete without learning its literature (Hişmanoğlu, 2005; Küçükolu \& Arikan, 2011; Syofyan, 2012; Ujjwala, 2013). Language is generally partitioned into two broad parts - linguistics and literature, and both are not isolated. Some pundits liken language to human beings wherein linguistics constitutes the 'skeleton' and literature makes its 'embedded soul'. For many years, literature was set apart from EFL and ESL programs with a primacy given to the grammatical rules of the target language, vocabulary, and communication skills. There is now a general sensuous on the possibility of teaching English through its literature (Arikan, 2005; Chen, 2014; Cox, 2012; Hişmanoğlu, 2005; Lazar, 2009; Novianti, 2016). The grammartranslation method considered literature a good fit to teach the grammar of the target language. Now the TESOL programs incorporate literature to expand the ecology of language learning and promote critical thinking skills and acculturation of the target groups of learners (Al-Tamimi, 2012; Haniya, 2019). By virtue of literature, learners understand symbols and expand their imagination. Nonetheless, findings accruing from substantial prior research have indicated that turning learners' attention toward literary imagination and the metaphysical world may not always be a fascination for the majority whose primary goal of joining a TESOL program is to use the language fluently. In light of this, programs preceded by learner needs analysis bound to be more successful. When given opportunities to voice 
their opinions, wishes, wants, and desires, learners - being the potential users of the target language are of paramount importance in needs analysis, which is an initial step in a learner-centered curriculum (Dudley-Evans \& St John, 1998; Hutchinson \& Waters, 1987; Long, 2005).

In recent curriculum development, a paradigm shift from teacher-dominance to learner-centeredness has become evident. There are also other associated shifts in terms of method to the post-method teaching (Kumaravadivelu, 2006), formal to informal learning (Cox, 2012), and traditional classroom to virtual classrooms. For these shifts to be a success, new trends, outlooks, and strategies are necessary. Such updates proffer learners a vast ground to be active rather than being passive recipients of knowledge. Amidst these curricular updates, learners have their own strategies that teachers should take into consideration. The Humanistic Curriculum views learners as active and productive participants in the learning process. It broadens the ecology of learning to include those moments during which learners are exposed to the target language independently from formal classes - while they are present online using various electronic and interactive platforms (Al-kadi, 2020). Students living at such an age are unexpected to go to the classroom as if they were "empty mugs to be filled with knowledge" by the teachers nor to be obedient receivers of teachers' long speeches and rigid teaching materials.

As documented in the syllabi of the English Department, Faculty of Education, introducing literature courses in the 4-year pre-service teacher training program aims at familiarizing the teacher candidates with different genres of literature and basic concepts of literary texts. It is essential to scrutinize how teacher preparation programs incorporate and handle literature courses. To the researchers' best knowledge, the program under study initiated in the early 1990s has remained unevaluated since then. The teachers follow it slavishly and abstain from trying insights beyond the given syllabi. Observably, learners attend the courses and pass the final exams. However, it is not clear whether the outcomes of the current teaching meet the objectives of those courses. Needs analysts (e.g., Dudley-Evans \& St John, 1998; Hutchinson \& Waters, 1987) asserted that neglecting learners' voices in designing their learning materials lead to fruitless outcomes. The pedagogical underpinnings and students' satisfaction in the context at hand remain largely unidentified. The gains supposed from incorporating the literature courses in the program are quite unsatisfactory. The graduates join the educational sector with a poor background, contrary to the stated purpose of instilling it in the program.

That is to say, there is a gap between the required and existing literary competencies of learners; their needs and the actual teaching do not match. This gap has to be bridged, and for this to happen, teacher intervention and curriculum update have to take place immediately. The current scenario indicates the necessity to revisit the syllabus and furnish an updated version, considering the current teaching trends. It is worthwhile to analyze the present situation with a focus on factors anchored to learning English literature. Hence, the present study intends to ascertain the load of literature courses embedded in the target program and succinctly elucidate the learners' needs for such courses. It probes the participants' perceptions and possible factors that affect learning/teaching literature of the target language in light of needs analysis, humanistic curriculum, learner-centered approach, and the postmethod perspective. More pointedly, this attempt centers on the following questions:

1. How do pre-service teachers generally perceive literature?

2. What motivates them to attend the literature classes?

3. How do they perceive the literature courses they currently undertake?

4. What major problems do they encounter in learning literature?

5. How do they overcome those problems? 
The present study is based on the learner needs analysis rather than the perceptional wishes of the curriculum designers. The findings delineate the current trends of literature teaching and learning at the university level. The inquiry departed from the localness of teaching materials to inform syllabus makers of the insightful ideas for curriculum reform (Kumaravadivelu, 2006). Drawing conclusions based on students' needs is an essential step in the Learner-centered Approach to course design, which has lately intrigued curriculum developers (Nunan, 1988; Tudor, 1996). By exploring the nature and types of difficulties pertaining to literature instruction, the study suggests measures for pedagogic improvement. Considering the learners' stance helps the curriculum reformers to make necessary amendments to the existing program. This attempt prioritizes learners' satisfaction that tops the learnercenteredness instilled in the humanistic approach to foreign language teaching.

\section{Literature Review}

The present study grounded in the humanistic curriculum, communicative language teaching (CLT), needs analysis, and post-method pedagogy is in tandem with theoretical underpinnings of teaching language through literature. These approaches place heavy emphasis on learners and learning (Daoud, 2017; Thornburry, 2011). While literature hardly existed in early ESL and EFL programs, it has gained currency in most of the textbooks and materials taught to learners under the auspices of CLT. When the communicative approach surfaced, literature had taken a position in the L2 curriculum. It has spilled over into an essential part of L2 programs. That is because language educators realized its spectacular contributions to L2 learning as it enhances language skills, critical thinking, and acculturation beyond the linguistic mechanism of learning a language. Syofyan (2012) enthusiastically argued that "literature is not only a tool for developing the written and oral skills of students but also is a window opening into the culture of the target language, building up a cultural competence in students" (p. 61). Al-Tamimi (2012) reasoned teaching language through literature. For instance, classical literature -the author argued - is suitable for teaching history and social background. Nevertheless, it is introduced in TESOL programs in the local context in such a way that yields unsatisfactory outcomes- the situation at Taiz University is case in point.

\subsection{Literature Teachability}

Seen as experience and imagination, literature mirrors society, reflects its historical experiences, and reveals the traditions, customs, and cultural heritage of a nation (Haniya, 2019; Syofyan, 2012). It is generally categorized into fiction, facts, content area texts, and newsreel. Fiction consists of poetry, drama, and prose. It is no exaggeration to say that going through a literary work is as enjoyable as going through life itself (Syofyan, 2012). Viewed in another light, literature is a platform for legends, myths, folktales, fairy tales, fables, fantasies, and historical fiction. It has been argued that teaching literature is not always straightforward, partly because "literature, and in particular poetry, has a way of exploiting resources in a language which has not been codified as correct usage...It has no place in an approach to teaching that insists on the gradual accumulation of correct linguistic forms" (Widdowson, 1984, p.162). When literature is introduced to students, masterpieces of well-known writers such as William Shakespeare, Metaphysician poets (e.g., John Donne, Milton) and Romantic poets such as William Wordsworth and poets of the twentieth century like T.S. Eliot are unavoidably studied to grasp the essentials of English language. Other literary works of post-colonialism and postmodernism are, of course, treasured to be included in TESOL programs. Such literary texts could be used as "sources of learning and the method of attaining cultural and linguistic content of the language (Haniya, 2019, p. 11). 
A study of literature includes defining and illustrating figures of speech such as simile, metaphor, personification, hyperbole, pun, synecdoche, tautology, oxymoron, alliteration, assonance, onomatopoeia, refrain, and the like. To illustrate these elements of literature, learners could be amply exposed to samples of texts chosen from different periods and genres (Haniya, 2019). Introducing techniques of literary compositions such as symbolism and imagery raises learners' awareness of the different ages of English literature and their characteristic features. Various terms denoting different forms of verse such as odes, songs, sonnets, lyrics, elegies, blank verse, couplets, quatrains, meters, the concept of the short story, long story, narrative fiction; Act and scene in a drama, tragedy, and comedy including burlesque and macabre may also be part of the program.

Teaching literature has undergone the sway of teacher-dominance pedagogy over the past decades, relying heavily- with few exceptions- on giving long lectures (Lang, 2018). In the post-method era, literature teaching requires a new approach that hosts learners' needs and variable teaching ideas. Williams (2017) suggested teaching poetry (e.g., Victorian poetry) with the psychology of the twentyfirst century. Smith (2017) called for teaching drama that he called the "forgotten genre". Crompton (2017) wrote about teaching literature through computing. Nichols (2017) wrote about teaching Victorian poets and novelists in the age of the Internet. These authors' calls for teaching literature increase the importance of literature for English learning. Besides teaching materials (e.g., textbooks, syllabus) and motivational, socio-cultural, linguistic background of the learners, schooling background in the target language is arguably an important factor along with the teachers' qualification/experience and professional growth. With these factors in mind, Chambers and Gregory (2006) opined that "teaching students to write about literary texts and topics is teaching them literature - which, in turn, seems to suggest that it is an important part of the literature teacher's job to teach students to write" ( $p$. $81)$.

\subsection{Teaching English through Literature}

Literature, which has gained momentum in the TESOL programs, is increasingly credited as a medium of teaching language (Chen, 2014; Hişmanoğlu, 2005; Syofyan, 2012; Ujjwala, 2013). This approach is based on the premise that literature facilitates acquiring language naturally and more comprehensibly (Arikan, 2005; Chen, 2014; Küçükolu \& Arikan, 2011; Syofyan, 2012; Türker, 2011). Incorporating components of English literature in TESOL programs has been rationalized in various ways. For instance, Hişmanoğlu (2005) speculated that various language aspects are teachable through literature. According to the author, in addition to language skill enhancement, literature upgrades learners' vocabulary, grammar, pronunciation, ambiguity, dramatization, role-playing, and symbolism. Likewise, Al-Tamimi (2012) postulated that teaching different genres of literature (e.g., poems, short stories, plays, and novels) has a myriad of benefits. The study highlighted that when appropriately taught, literature increases understanding between diverse communities. Besides natural language presented in pieces of literature, it promotes socio-cultural understanding and awareness. It also helps to create lifetime readers. Debating that linguistic competence is (a) necessarily associated with cultural competency defined as a set of values, beliefs and perceptions of the target language, and (b) suitably taught through literature, Al-Tamimi queried how literature bridges the cultural gap between L2 students and the target language community and how it enables them to become fluent in the target language.

In a similar vein, Arikan (2005) evaluated the literature curriculum in Turkey by surveying 15 teachers and 100 students affiliated to the English Language Teaching (ELT) Department at the Faculty of Education, Hacettepe University. The respondents viewed the literature courses as an essential part of their pre-service education. Likewise, Chen (2014) asserted that literature of the target language is 
effective to acquire the language itself. To Chen, literature-based language input is challenging for learners, which enriches their linguistic repertoire in terms of vocabulary, structures, oral and written skills. It is safe to say that teaching English through literature is a viable technique in a TESOL program. It is not uncommon that literature teachers or TESOL programs treat it as a tool or resource to help students learn English (Syofyan, 2012; Türker, 2011). Apart from being a pleasure, studying literature exposes learners to genuine and authentic materials of the target language (Haniya, 2019). It is also beneficial for them to understand other nations' cultures and thus decrease the schism in cultural gaps between nations (Al-Tamimi, 2012; Benattabou, 2020; Razak et al., 2020).

Despite these advantages, teaching literature is not always an easy task. It has been widely argued that teaching literature in EFL and ESL contexts that generally think of it as less important than linguistic aspects is quite challenging. Students in such contexts learn English for specific purposes but not for mere enjoyment and exploring the world (Novianti, 2016). Ujjwala (2013) noted that literature teachers used the "traditional method of lecturing on topics like theme, characterization, plot, motifs directly without giving any emphasis on the linguistic/stylistic aspect of the literary text they teach" (p. 1). Likewise, Haniya (2019) noted an obvious "mismatch between literature as a contentbased subject and literature as a rich authentic material used in language classes" (p. 2). Novianti (2016) postulated that learning literature for the sake of literature does not always help learners to get a job or interact with other English users at work or in business. Hence, the onus is on pedagogues to stimulate learners' appetite for literature.

\section{Methodology}

The study took place at the Faculty of Education, Taiz University, where prospective teachers are trained to be school teachers. The EFL teacher preparation program stretches over four years, divided into eight semesters (two semesters each year). Each semester has an average of 12-15 credits for each course in the program. The study, descriptive in nature, adopts a quantitative research design with some space in the survey for qualitative data to add depth to the investigation.

\subsection{Participants}

Using students as informants was rationalized by Long's (2005) contention that learners "are often the primary, sometimes the only respondents; they not only wish to be consulted but also are wellinformed" (pp.19-20). Senior teacher candidates constituted the primary source of information in this study. All the pre-service teachers enrolled in the program in focus $(n=112)$ were invited for an online opinion poll. This cohort, aged between 23 and 27, were selected at their last stage of the training (level IV) because they were, assumingly, familiar with literature more than their juniors were. During their enrollment in the program, they were trained to become teachers of English. Guided by the course descriptions, the entrants develop language proficiency at the first level and professional competence and a taste for independent practical learning in the following three levels.

\subsection{Survey}

Being familiar with the context of the study, the researchers phrased questions of the questionnaire to poll information related to problems, priorities, abilities, attitudes, and solutions. The survey was designed with a flashback on Lazar's (2009) Literature and Language Teaching. It consisted of 36 questions, varying from self-ratings, judgmental ratings, and multiple-choice questions. Questions concerning basic information such as gender, age, and language experience before college were incorporated into the first part. The second part comprised questions about how the participants perceived literature and its different forms. The third part, which is an attitudinal question, elicited 
information on how frequently they attended the literature classes and the reasons behind their attendance. Finally, an open-ended question placed at the end of the survey required substantial and creative writing. It gave the informants an opportunity to write their comments regarding the topic in focus - information that could not be collected through close-ended questions.

\subsection{Course Description}

The program the informants undertook comprised two types of courses - courses directed towards linguistic competence and some other courses that lead to developing skills in educational and social sciences that are deemed necessary for the prospective schoolteachers. The required courses (elective) taught in coordination with other specialized departments within the Faculty of Education included the Department of Psychology, the Department of Curriculum and Methodology, and the Department of Educational Foundations. The course description outlines all the courses in the program with stated objectives, learners' characteristics, teaching methods, approaches, and procedures that explain how

Table 1. Literature Courses in the Teacher Training Program, Faculty of Education, Taiz University

\begin{tabular}{|c|c|c|c|c|c|}
\hline \multicolumn{6}{|c|}{ LEVEL I } \\
\hline No & COURSES & $\mathrm{CH}$ & No & COURSES & CH \\
\hline & First Semester & & & Second Semester & \\
\hline 1 & Reading and Composition I & 3 & 1 & Reading and Composition II & 3 \\
\hline 2 & English Grammar I & 3 & 2 & English Grammar II & 3 \\
\hline 3 & Int. to Literary Forms I & 3 & 3 & Int. to Literary Forms II & 3 \\
\hline \multirow[t]{2}{*}{4} & Spoken English I & 3 & 4 & Spoken English II & 3 \\
\hline & Total & 12 & & Total & 12 \\
\hline \multicolumn{6}{|c|}{ LEVEL II } \\
\hline \multirow[t]{2}{*}{ No } & COURSES & $\begin{array}{l}\mathrm{C} \\
\mathrm{H}\end{array}$ & No & COURSES & $\underset{\mathbf{H}}{\mathbf{C}}$ \\
\hline & First Semester & & & Second Semester & \\
\hline 1 & Reading and Composition III & 3 & 1 & Reading and Composition IV & 3 \\
\hline 2 & English Usage I & 3 & 2 & English Usage II & 3 \\
\hline 3 & Spoken English III & 3 & 3 & Spoken English IV & 3 \\
\hline 4 & Int. to Language I & 2 & 4 & Int. to Language II & 2 \\
\hline 5 & Translation I & 2 & 5 & Translation II & 2 \\
\hline 6 & 18 Century Novel & 3 & 6 & Elizabethan Drama (Jacobean) & 3 \\
\hline \multirow[t]{2}{*}{7} & Curriculum I & 2 & 7 & Curriculum II & 2 \\
\hline & Total & 18 & & Total & 18 \\
\hline \multicolumn{6}{|c|}{ LEVEL III } \\
\hline \multirow{2}{*}{$\mathbf{0}^{\mathbf{N}}$} & COURSES & $\mathrm{CH}$ & No & COURSES & $\mathbf{C H}$ \\
\hline & First Semester & & & Second Semester & \\
\hline 1 & English Phonology & 3 & 1 & Eng. Morphology and Syntax & 3 \\
\hline 2 & English Discourse & 3 & 2 & Analysis of Literary Texts & 3 \\
\hline 3 & 19 Century Novel & 3 & 3 & 18 Century Drama & 3 \\
\hline 4 & 17 Century Poetry & 3 & 4 & Romantic Poetry & 3 \\
\hline \multirow[t]{2}{*}{5} & Special Teaching Skills & 2 & 5 & Methods of Teaching Eng1 & 2 \\
\hline & Total & 14 & & Total & 14 \\
\hline \multicolumn{6}{|c|}{ LEVEL IV } \\
\hline \multirow[t]{2}{*}{ No } & COURSES & $\mathrm{CH}$ & No & COURSES & CH \\
\hline & First Semester & & & Second Semester & \\
\hline 1 & Advanced Writing Skills & 3 & 1 & History of English Language & 3 \\
\hline 2 & T G Grammar & 3 & 2 & Topics in Applied Linguistics & 3 \\
\hline 3 & 20 Century Drama & 3 & 3 & 20 Century Novel & 3 \\
\hline 4 & 20 Century Poetry & 3 & 4 & $/ / /$ & -- \\
\hline \multirow[t]{2}{*}{5} & Methods of Teaching Eng 2 & 2 & & & \\
\hline & Total & 14 & & Total & 9 \\
\hline
\end{tabular}

Source: The Dept. of English, Faculty of Education, Taiz University 
each course had to be implemented. For this inquiry, only the courses taught in English are tabulated and arranged in Table 1. The courses of literature are the focus of the analysis. As indicated in the table, the entrants, during the first year, are taught basic skills - listening, speaking, reading, writing, and an introduction to literature. In the second and third years, students undertook advanced courses in linguistics. Subjects like Phonology, Phonetics, Morphology, and Syntax were assigned to this stage. In addition, some literature courses are embedded in the program at this level. Throughout the program, students need advanced English skills to make progress in their studies and pass examinations. As students proceed to the fourth year, a transitional stage, they transfer from theory to practice. They are prepared for teaching at school. They go to school one day a week for practicum.

\subsection{Procedures}

Before conducting the survey, an initial version was piloted on a group of learners with similar characteristics to check how it would work in reality. The reliability and validity parameters were checked, and the psychometric features were reasonably adequate (.87). An approved version of the survey was designed to fill out online. Upon prior arrangements with the headteachers and dean of the institution, the researchers attended one literature class. They directed students to the electronic link of the study to complete the form online. In the pilot study, ten participants were asked to read and complete the questionnaires in the presence of the researchers. Modifications were done before approving the final version that was converted into a soft copy for online access. The survey yielded quantitative results, which required an appropriate technique of analysis. The dataset was first screened and cleaned for outers, and by using IBM SPSS 25, statistical analysis procedures were applied. Responses were coded, clustered, and tabulated. Clustered in such a way to correspond to the research questions, the results were interpreted in light of similar previous findings and theoretical underpinnings of teaching language through literature.

\subsection{Data analysis}

Significant results ensued from the analysis are arranged in compliance with the research questions. Two types of data were treated: quantitative and qualitative data. The quantitative data were converted into numbers, summarized, and presented visually with appropriate discussion. The frequencies, percentages, mean values, and standard deviations helped find answers to the research questions based on statistical analysis. The qualitative data (ensued from the open-ended concluding question in the survey), on the other hand, were converted into patterns/categories and illustrative quotations. In such a mixed analysis of qualitative and quantitative data, numbers are used to add precision to categories and patterns that add meaning to numbers. In the analysis, the poetry courses were considered as one component (poetry) and similarly novel and drama - that is, poetry comprised metaphysical Poetry, Romantic Poetry and twentieth Century Poetry. As well, drama included Elizabethan Drama, eighteenth Century Drama, and twentieth Century Drama. Similarly, the novel included the eighteenth century Novel, nineteenth Century Novel, and twentieth Century Novel.

\section{Results and Discussion}

The study at hand set out to explore how the prospective English language teachers perceived the teaching of literature in the program they joined. It dwells on this syllabus, specifically the literature courses slotted in the program.

\subsection{Pre-service Teachers' Perceptions of Literature}

The informants' perceptions on studying literature were measured statistically. For this purpose, a Likert scale, ranging from 1 to 5 , was used in which 1 stands for being 'strongly agree' and 5 'strongly 
disagree'. The results obtained from Question 9 in the survey are outlined in Table 2. For ease of analysis and interpretation closer values $(1 \& 2)$ were clustered as one unit depicting agreeing), and similarly, the numeric values 4 and 5 were considered another counterpart unit (disagreeing) and the third unit represented undecidedness.

Table 2. Pre-service Teachers' Perceptions of Literature

Percentage of respondents

\begin{tabular}{|c|c|c|c|}
\hline Items included in the analysis & $\begin{array}{c}\text { in } \\
\text { Agreement }\end{array}$ & $\begin{array}{c}\text { in } \\
\text { Disagreement }\end{array}$ & $\begin{array}{c}\text { Un- } \\
\text { decided }\end{array}$ \\
\hline Literature is an important thing in my life. & $6 \%$ & $84 \%$ & $10 \%$ \\
\hline Literature has changed the way I see the world. & $12 \%$ & $78 \%$ & $10 \%$ \\
\hline Literature helps me improve learning ideas. & $00 \%$ & $83.3 \%$ & $16.7 \%$ \\
\hline It helps me to understand and appreciate other cultures & $00 \%$ & $91.7 \%$ & $8.3 \%$ \\
\hline $\begin{array}{l}\text { It provides useful examples of syntax and language } \\
\text { usage. }\end{array}$ & $12.5 \%$ & $58.3 \%$ & $29 . \%$ \\
\hline It encourages me to pursue additional readings in English. & $4.2 \%$ & $83.3 \%$ & $12.5 \%$ \\
\hline $\begin{array}{l}\text { It helps me become more effective communicator in } \\
\text { English. }\end{array}$ & $8.3 \%$ & $62.5 \%$ & $29.2 \%$ \\
\hline It enriches my vocabulary. & $00 \%$ & $91.7 \%$ & $8.3 \%$ \\
\hline $\begin{array}{l}\text { Literature inspires me to think over painful or beautiful } \\
\text { aspects of life. }\end{array}$ & $8.3 \%$ & $87.5 \%$ & $4.2 \%$ \\
\hline
\end{tabular}

As data in the table indicates, 92 percent of the participants stated that literature had no significant role in enhancing their acculturation and communication in the target language. They also stated that it did not enrich their vocabulary (91\%), nor did it encouraged additional reading (83\%) or learning ideas (83\%). This is odd with Chen (2014) who capitalized on the literature of the target language to promote learners' vocabulary, structures, oral and written skills. Eighty four percent of the participants disregard literature in their life for they thought it did not inspire them to think over life aspects $(87 \%)$. In terms of linguistic abilities, they thought it did not promote their learning and syntactic structures and patterns they were unfamiliar with before studying literature (58\%). It appears that literature is insignificant to these learners and they thought the courses were imposed on them. This result was reinforced by the result of the question on reasons for studying English literature as displayed in Fig.1.

\subsection{Motivation of Attending the Literature Classes}

So long as literature instruction undergoes striking difficulties, Figure 1 outlines the motives that drive learners to attend literature classes as elicited by tallies in the survey (Q 15). As seen in the figure, the most striking motivation behind attending the courses is that it is compulsory. In addition, a few stated that the class was interesting and a minority thought attendance was mainly for exams. Believingly, attending literature classes instigated by the demand of the examination system detriments the essential purpose of incorporating literature in L2 programs.

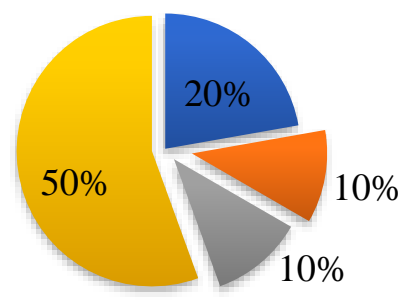

It is compulsory

The class is very interesting

I like literature very much

The exams

Figure 1. Reasons for Attending Literature Courses 
The results in both Table 1 and Figure 1 could be attributed to the fact that learners are not consulted in determining what to study and what to include/exclude in their study - i.e., it needs to be dictated by the learners' needs approach. In this regard, Richards (2001) opined that what students are taught should be "restricted to what they need" (p. 32). Richards' contention is aligned with other authors such as Dudley-Evans and St John (1998) and Hutchinson \& Waters (1987) who claim that students become capable of performing better in their field of study if they are taught what they need. Thus, it is challenging to motivate learners and instill a sense of literature without meeting their learning needs. The beginning would be from solving everyday problems that make literature instruction a difficult mission.

\subsection{Learners' Perceptions of the Literature Courses}

In Table 1 above, the participants' responses regarding their perceptions of literature were discussed. It is even important to probe their perceptions of the literature courses they attend as part of the pre-service teacher training program at their college. To correspond to the third research question, the responses (in terms of tallies) are summarized in Figures 2 and 3. The results illustrated in both figures showcase informants' perceptions of the courses they undertake at the Faculty of Education. Figure 1 shows that 47 percent of the respondents think those courses were irrelevant to their future career, though a considerable percentage of the respondents thought it was not a waste of time to study literature.

More relevant evidence is outlined in Figure 2 in which the majority of the respondents thought the courses were handled inaccurately. This has led to the dissatisfaction of half of the respondents who suffer lack of objectives and qualified teachers. They also believe the teaching methods were improper. In response to the open-ended question in the survey (Q16), Teacher 1 advocated

"I memorize text to write it in the exam paper and that's all."

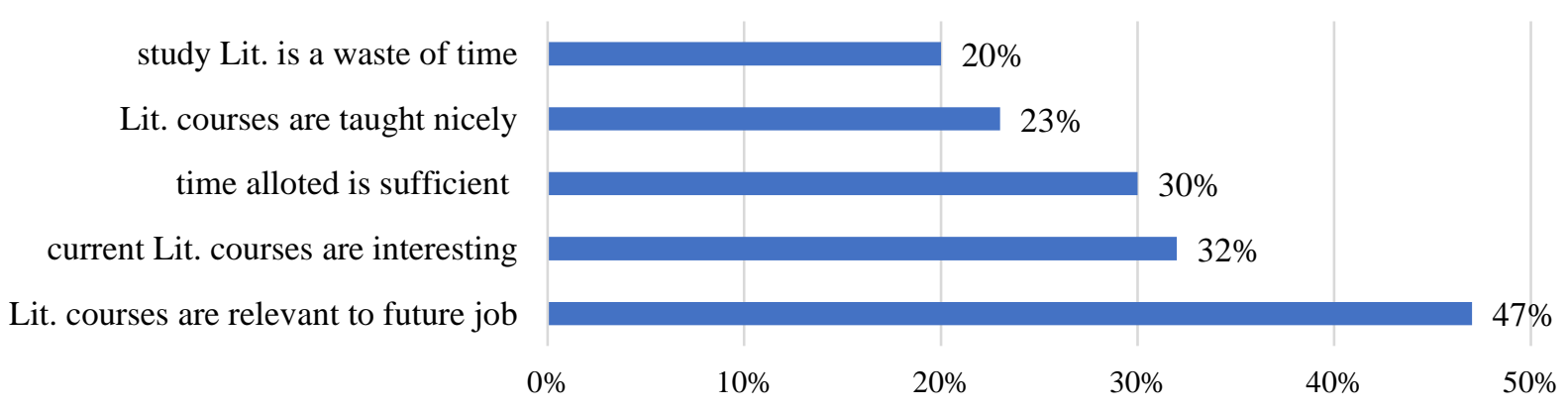

Figure 2. Informants' Perceptions of Teaching Literature Courses at Faculty of Education

In the given dataset, a high percentage of the informants believed literature courses were entirely irrelevant to their future jobs and they thought studying literature is a waste of time. Perhaps, these two issues were fueled by the erroneous literature syllabus and the methodology in use. In this light, there is a need to reorient students' attitudes toward literature, and the onus is on literature teachers to make this possible. As reflected in Figure3, real problems also included what Haniya (2019) argued for, "the curriculum sometimes does not specify what and how literature should be taught in a course" (p. 3). 


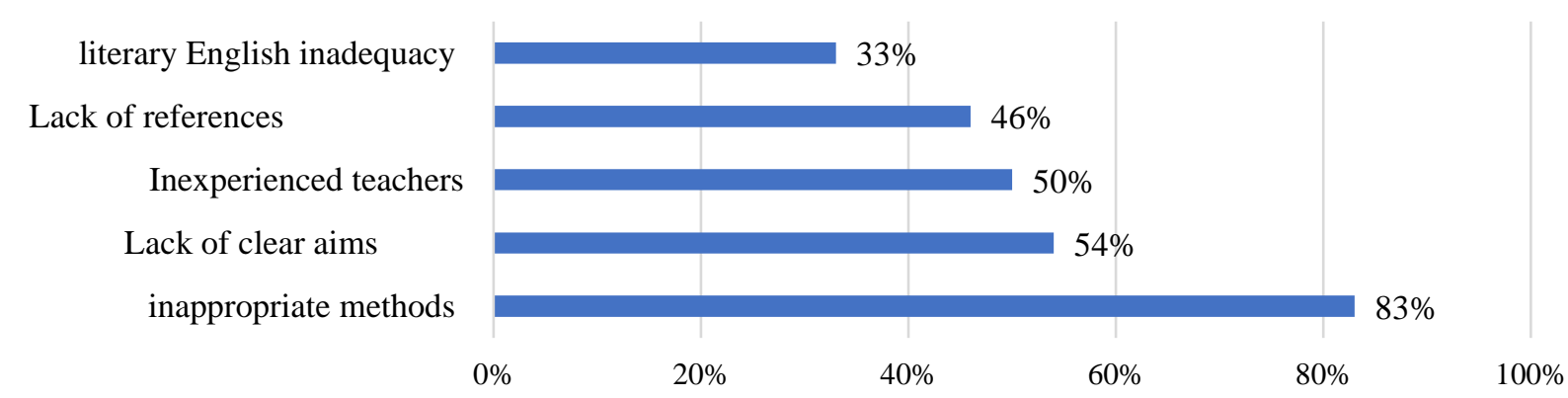

Figure 3. Common Problems of Teaching Literature Courses

\subsection{Major Problems of Learning Literature}

To address this research question, the informants' responses to Q10 in the survey were obtained and arrange in Table 3. They are analyzed further by using the mean scores and standard deviations. The informants' perceptions of such difficulties were measured using a Likert five-point scale ranging from 1 to 5 with 1 being problematic and 5 not problematic. Data in the table illustrates the difficulties within the literature courses. As can be seen in the table, the most challenging courses to the participants were Literary Text Analyses, followed by Drama, Poetry, and Novel with overall mean scores $10.3,10.7,11.7,12.1$, and 12.7 respectively. Perhaps, this is because the analysis of literary

Table 3. Students' Perceptions of Difficulties in Learning Literature Courses

\begin{tabular}{|c|c|c|c|c|}
\hline Course & Challenges & Mean & SD & $\begin{array}{c}\text { Overall } \\
\text { Mean }\end{array}$ \\
\hline \multirow{5}{*}{ 莺 } & Lack of literary words, items, etc. & 2.7 & 1.19707 & \multirow{5}{*}{12.1} \\
\hline & Lack of introduction to the topic. & 2.8 & 0.97709 & \\
\hline & Difficult language. & 2.0 & 1.26763 & \\
\hline & Poor teaching methods of the course. & 2.0 & 1.12208 & \\
\hline & Lack of interest. & 2.6 & 1.43898 & \\
\hline \multirow{5}{*}{ 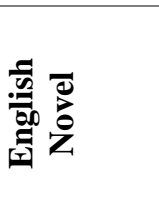 } & Reading long novels. & 2.5 & 1.28466 & \multirow{5}{*}{12.7} \\
\hline & The subject matter of the novel. & 2.9 & 1.1156 & \\
\hline & The picaresque tradition. & 2.9 & 0.94696 & \\
\hline & Poor teaching methods of novels. & 2.0 & 1.16018 & \\
\hline & Lack of interest. & 2.4 & 1.28255 & \\
\hline \multirow{5}{*}{ 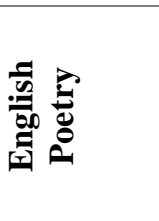 } & Lack of metric language. & 2.1 & 1.01795 & \multirow{5}{*}{11.7} \\
\hline & Difficult to memorize lines. & 2.3 & 1.23945 & \\
\hline & Poor teaching methods of poetry. & 2.1 & 1.36135 & \\
\hline & Use of imagery and blank verse & 2.8 & 1.32698 & \\
\hline & Lack of interest. & 2.4 & 1.34528 & \\
\hline \multirow{5}{*}{ 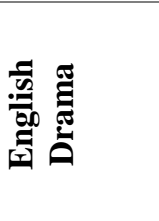 } & Lack of matching theory with real acting. & 2.1 & 0.85019 & \multirow{4}{*}{10.7} \\
\hline & Lack of dramatic background (no theater). & 2.3 & 1.18872 & \\
\hline & Poor teaching methods. & 1.8 & 1.00722 & \\
\hline & use of imagery and blank verse & 2.4 & 1.40844 & \\
\hline & Lack of interest. & 2.1 & 0.85019 & \multirow{6}{*}{10.3} \\
\hline \multirow{5}{*}{ 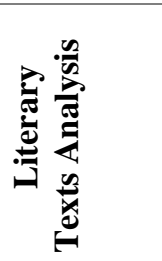 } & Lack of tools of analysis & 1.7 & 0.7506 & \\
\hline & Lack of critical thinking. & 2.3 & 0.91683 & \\
\hline & Lack of concrete models. & 2.2 & 1.12932 & \\
\hline & Poor teaching methods. & 2.1 & 1.21285 & \\
\hline & Lack of interest. & 2.0 & 1.16018 & \\
\hline
\end{tabular}

Scale: $1=$ very problematic $; 2=$ problematic; $3=$ neutral; $4=$ not problmatic; $5=$ not very problmeatic 
texts requires advanced language skills and criticism that the respondents lag behind. Likewise, because students join the program without previous background on literature at school, they stated that the introduction to literary forms, which is introduced at the entry-level was also problematic. In contrast, the least difficult as shown in the table is the Novel course. This verifies that reading a novel, which is, in essence, a long story has been articulated as less challenging than other literary genres, unlike poetry and drama, which have been perceived as the most challenging literature courses in the program in focus. This is important for educators and syllabus designers to know the difficulty level and consider that when designing the syllabi.

Within these areas of literature, major problems were threefold: (a) lack of interest, (b) teaching methods, and (c) literary language. Lack of interest scored an overall mean value 8.9, and the teaching methods scored 10.00. Poor teaching methods of novel, poetry, drama and literary text analysis scored relatively high mean values. The common and widely used method is lecturing - a lecture extends for 3 hours. This makes it dull and requires a variety of teaching methods beyond lecturing. It is challenging then how to motivate learners and instill a sense of literature in them. Teaching should vary from lecturing to seminars, workshops, tutorials, websites, and online. For this purpose, Lazar (2009) and Chambers and Gregory (2006) might be good references for teachers to satisfy this requirement. From the post-method stance, students' desire and necessity make them learn a language and its literature whatever the methods used (Davies, 2007).

As seen in Table 3, learners had a problem in treating the literary genres. As for the novel, difficulty manifested itself, besides reading long novels, in the subject-matter of the novel and picaresque tradition. These dovetail with the difficulty of memorizing verse; the respondents stated that metric language was also another major challenge to study poetry. Again, the drama course exposited some more problems. For instance, they found blank verse and imagery challenging, in addition to lack of theory to match real acting and lack of theater at the university. Last but also equally important, the Introduction to Literary Forms and Literary Text Analysis courses added more challenges. In the former, which is taught at the first level, the respondents stated that they lacked literary words, terms and jargon, and in the latter, they lacked analysis tools.

More data emerged from the open-ended question, which was subject to qualitative analysis. The lengthy comments that information provided were clustered around a theme. The most noteworthy notes the informants provided included (a) lack of courses in English history that facilities understanding literature throughout the centuries and (b) lack of textbooks and suitable references. The teaching materials included handouts and references, which were generally not fashioned to learners' needs.

In response to the open-ended question in the survey, Teacher 2 commented,

"In studying the literature course, the only accessible materials are those handouts given by the teacher."

Another participant added,

"I don't feel like furthering reading beyond those handouts because the literary language is complicated, and I do not have time to consult the dictionary every time and then".

Taken together, common problems militating against effective learning of literature courses in the given context include inadequacy of slotting in courses in the program, unobvious objectives of teaching literary forms, unqualified teachers, and ill-prepared materials (Arikan, 2005; Chen, 2014; Haniya, 2019). In the present study, the shared difficulty in all the courses is the literary language. 
This is perhaps learners are not adept at using literary language for they join the EFL program at college with little or no prior knowledge of literature. This suggests revisiting the EFL program at the school level. Another important point to underscore here is the teaching methods. The informants attributed difficulties to teaching methods. In the given context, the sole method of teaching all the literature courses is lecturing - chalk and talk. Again, the teachers who teach such courses usually are teachers trained on method-orientation and find it uneasy to shift to the post-method which grans teachers ground for innovation and inventing their own methods (Kumaravadivelu, 2006). They are, in other words, theory appliers rather than theory explorers and constructors. These difficulties largely corroborate the results in previous studies (e.g., Arikan, 2005; Küçükolu \& Arikan, 2011; Novianti, 2016; Türker, 2011). The challenges reported in this study understandably have a broader context, and perhaps corrective interventions in such contexts would be useful to the context of the present study, and vice versa.

\subsection{Overcoming Difficulties}

Given the aforementioned problems, it is fitting to examine how learners go about these intricacies. Based on responses to Q 11, response tallies were obtained and arranged in Figure 4. As displayed in the figure, the learners tend to use some strategies that facilitate learning literature, including locating answers on the Internet and memorizing texts. This shows, to a large extent, the dominance of learning by memorizing, and equally important that learners tend to troll the Internet to find answers to their questions. They tend to be less reliant on teachers and more dependent on the websites when they had problems with their literary studies. It has been observed that a large number of students hardly interacted with their teachers either in participating in their classes or in visiting them at their office for discussing their language learning problems. This calls for amending the debilitating relationship between learners and their teachers (Kumaravadivelu, 2006).

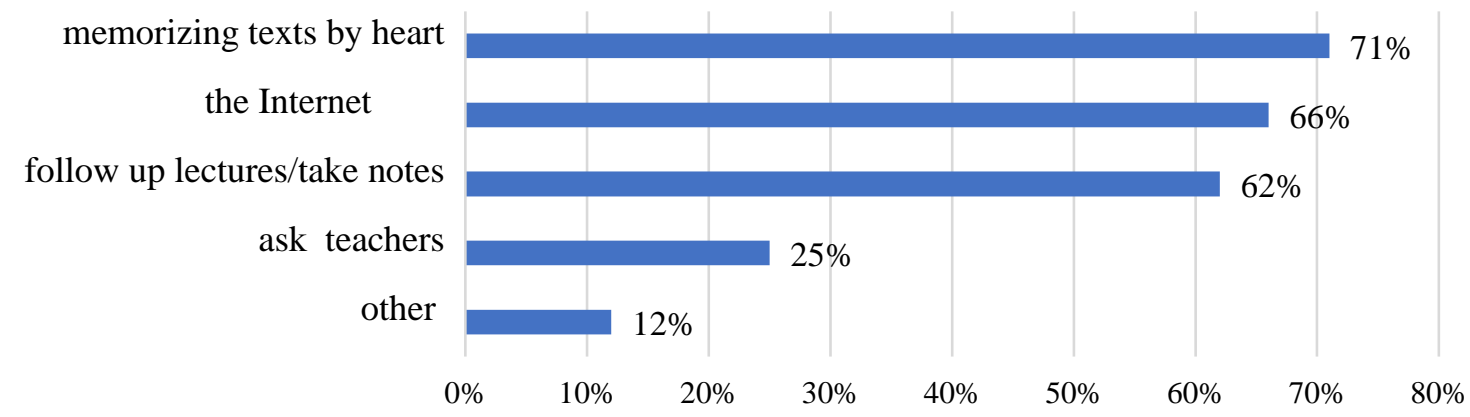

Figure 4. The Participants' Practices of Learning Literature Course

Noticeably, the literature courses incorporated in the program under scrutiny (outlined in Table 1) were designed in the 1990s. The syllabus comprised English literature courses that covered major English literary works from the Middle English period (1150-1500) until the twentieth century. By analyzing the course description, components from T.S. Eliot's poetry were included in addition to some other poets' works such as Yeats, Philip Larkin, and Wallace Stevens. However, much has been written after Eliot's period that could be included in the syllabus as well. For instance, postcolonial and post-modernism writers could enrich the syllabus. Again, the majority of the literature courses in the program has no place for American literature or literature written in English by authors whose first language is not English or lived on non-English land or that used to be colonies. The findings, when taken together, show the necessity of an urgent update. A revised version of the program could undertake all of these issues. Cox (2012) lays down a sensible view of literature teaching in her book, Literature-based Teaching in the Content Areas. The publication provides 40 literature-based 
strategies on how to go about literature in the classroom. These strategies are beneficial for pre-service teachers to gain practical experiences in their early career and students teaching in content areas. Teachers can dip in and select from those strategies that dovetail with their teaching context. Following Haniya (2019), criteria for selecting literary materials include appropriateness for students' culture, background, age, and interests. Selecting the texts or materials, the author argued, depends on not only the materials themselves but also their deliverer.

\section{Implications}

Because literature is not primarily made to fulfill pedagogical purposes (Haniya, 2019), teachers with linguistic prowess and beauty of literature should devise learnable interesting and preferably contextsensitive literary texts: plays, poems, stories, and prose that help learners discover the language features. That language used in teaching literature is difficult warrants for simplifying language to fit the learners' linguistic level to facilitate learning the target texts. The selection of materials (books and topics) would work better if they were in tandem with learners' real-life experiences, emotions, and dreams. The selection should be a possible fit that reflects the aims and objectives of the program under which the literature courses are undertaken. The materials would include child literature, feminisms, and other recent issues.

It is also implicated that materials designed in congruency with learners' existing experiences likely engage both teachers and learners (Hişmanoğlu, 2005). Varying teaching methods and techniquesbeyond the long-established method of 'chalk and talk' is another important factor that stimulates learners' interest in literature. Teachers should play various roles in lieu of the traditional dominant roles. They could integrate modern digital technology into their classes, for instance, to let students watch a filmed novel or play and listen to well-recited poems. They could also engage learners in collecting relevant materials for classes or acting on short sketches. That is to say, learners' should be part of the process of instruction - learning by doing rather than dictating. Literature teaching should include informal learning that students practice every day. The drama could be manipulated to teach dialogue in everyday conversational English. Drama helps learners to "become familiar with grammatical structures in contexts and also learn about how to use the language to express, control and inform" (Ujjwala, 2013, p.3). Similarly, poetry can be employed to teach stress and rhythm, and novel for teaching reading. Long novels could be assigned as part of extended reading (free reading outside the classroom). That is, studnets should imbibe literature by making it alive in their day-to-day lives. Only then can teaching literature refines their sense of literary appreciation.

Alongside the teaching methods and text selection, there are implications for alternative assessment. The existing evaluation that is solely based on written exams should be modified. Teaching literature for the purpose of exams bounds to be fruitless and a waste of time and effort. The traditional examination system may be substituted by or used together with self-assessment (Cox, 2012). Students should be encouraged to hand in written assignments on topics that interest them.

\section{Conclusion}

Departing from the learners' needs for literature, this paper queried how literature courses are nested within a teacher preparation program. It pinpointed how pre-service teachers perceived literature, difficulties of and motivations for taking literary courses. Findings ensued from this analysis show that the program underwent challenges that should be treated immediately. The endeavor suggests possible procedures for updating the exisintg program that should be fashioned to a new purpose, a new footing, and a new perspective in line with the worldwide extemporized changes in curriculum development. The findings stimulate some recommendations for educators and curriculum developers to act on such 
conundrums. The study is limited to the prospective teachers' views; other participants such as literature teachers and policymakers might have provided more insights into the current investigation - such stakeholders may have their own reasons of the current status quo; understating those reasons may explain some points of the inquiry. Still, as it stands, this work helps teachers and curriculum designers to gain more understating of learners' difficulties of learning literature and act accordingly.

\section{References}

Al-kadi, A. (2020). Informal language practices via digital technology: The neglected proficiency. In R. Ahmed, A. Al-kadi \& T. Hagar (Eds), Enhancements and limitations to ICT-based informal language learning: Emerging research and opportunities (pp. 1-23). Hershey PA: IGI Global.

Al-Tamimi, H. (2012). Teaching literature to foreign language learners as a medium for cultural awareness and empathy. Arab World English Journal, 3(40), 214-232.

Arikan, A. (2005). An evaluation of literature component of Hacettepe University English language teaching department. Hacettepe University Journal of Education, 29, 40-49.

Benattabou, D. (2020). Helping EFL Students Avoid Socio-pragmatic Failure: Focus on Nonverbal Intercultural Competence. TESOL and Technology Studies, 1(1), 23-41.

Chambers, E. \& Gregory, M. (2006). Teaching and learning English literature. London: Sage Publications.

Chen, M. (2014). Teaching English as a foreign language through literature. Theory and Practice in Language Studies, 4(2). 232-236.

Cox, C. (2012). Literature-based teaching in the content areas. Thousand Oaks, California: SAGE Publications.

Daoud, M. (2017). Teaching English in turbulent times: Curriculum savvy teachers for curriculum success and sustainability. British Association for Applied Linguistics. 50 ${ }^{\text {th }}$ Annual Meeting. https://www.youtube.com/watch?v=DUZPrJ1VliM\&feature=youtube.

Davies, A. (2007). An introduction to applied linguistics: From practice to theory ( $2^{\text {nd }}$ ed). Edinburgh: Edinburgh University Press.

Dudley-Evans, T. \& St John, M. (1998). Developments in English for specific purposes: A multidisciplinary approach. Cambridge: CUP.

Haniya, A. (2019). Literary materials selection for teaching English language and literature subject at Senior High Schools in Sidoarjo (thesis). English Education Department, Faculty of Education and Teacher Training. UIN Sunan Ampel Surabaya.

Hişmanoğlu, M. (2005). Teaching English through literature. Journal of Language and Linguistic Studies, 1(1), 53- 66.

Hutchinson, T. \& Waters, A. (1987). English for specific purposes: A learner-centered approach. London: CUP.

Kumaravadivelu, B. (2006). Understanding language teaching: From method to post method. Mahwah. N. J.: Lawrence Erlbaum Associates. 
Küçükolu, H. \& Arikan, A. (2011). Prospective English language teachers' views on literature in their teacher education curriculum and its potential value. Procedia Social and Behavioral Sciences $15,1718-1722$

Lazar, G. (2009). Literature and Language Teaching: A guide for teachers and trainers. Cambridge: CUP.

Lang, J. (2018). Introduction. In G. Dujardin, J.M. Lang \& J. A. Staunto (Eds.), Teaching the literature survey course (pp. 1-10). Morgantown: West Virginia University Press.

Long, M. (2005). Second language needs analysis. Cambridge: CUP.

Nichols, A. (2017). Ecocritical and environmental approaches: Teaching Victorian poets and novelists in the age of the Internet. In J. Cadwallader \& L. W. Mazzeno (Eds.), Teaching Victorian literature in the twenty-first century (pp. 315-328). Gewerbestrasse: Palgrave Macmillan.

Novianti, N. (2016). English literature teaching: An Indonesian context. Indonesian Journal of Applied Linguistics, 6(1), 42-49.

Nunan, D. (1988). The learner-centered curriculum. Cambridge: CUP.

Razak, N. A., Ahmad, N. F. B., Suhaimi, N. B., Saidin, K. N. B., \& Mahda, A. A. B. (2020). Multilingualism and Multiculturalism Impact on Shaping Oral Literacy and Communicative Competence. TESOL and Technology Studies, 1(1), 42-54.

Smith, J. (2017). Teaching the 'forgotten' genre: Victorian Drama. In J. Cadwallader \& L. W. Mazzeno (Eds.), Teaching Victorian literature in the twenty-first century (pp.167-180). Gewerbestrasse: Palgrave Macmillan.

Syofyan, D. (2012). Teaching English through literature. Indonesian Journal of English Language Teaching, 8(2), 51-61.

Williams, T.O. (2017). Teaching Victorian poetry with twenty-first-century psychology. In J. Cadwallader \& L. W. Mazzeno (Eds.), Teaching Victorian literature in the twenty-first century (pp. 155-166). Gewerbestrasse: Palgrave Macmillan.

Tudor, I. (1996). Learner-centeredness as language education. Cambridge: CUP

Thornbury, S. (2011). Language teaching methodology. In J. Simpson (Ed.), The Routledge handbook of applied linguistics (pp. 185-199). New York, NY: Routledge.

Ujjwala, K. (2013). English language teaching through literature. Golden Research Thoughts, 2(11), 1- 4. 